
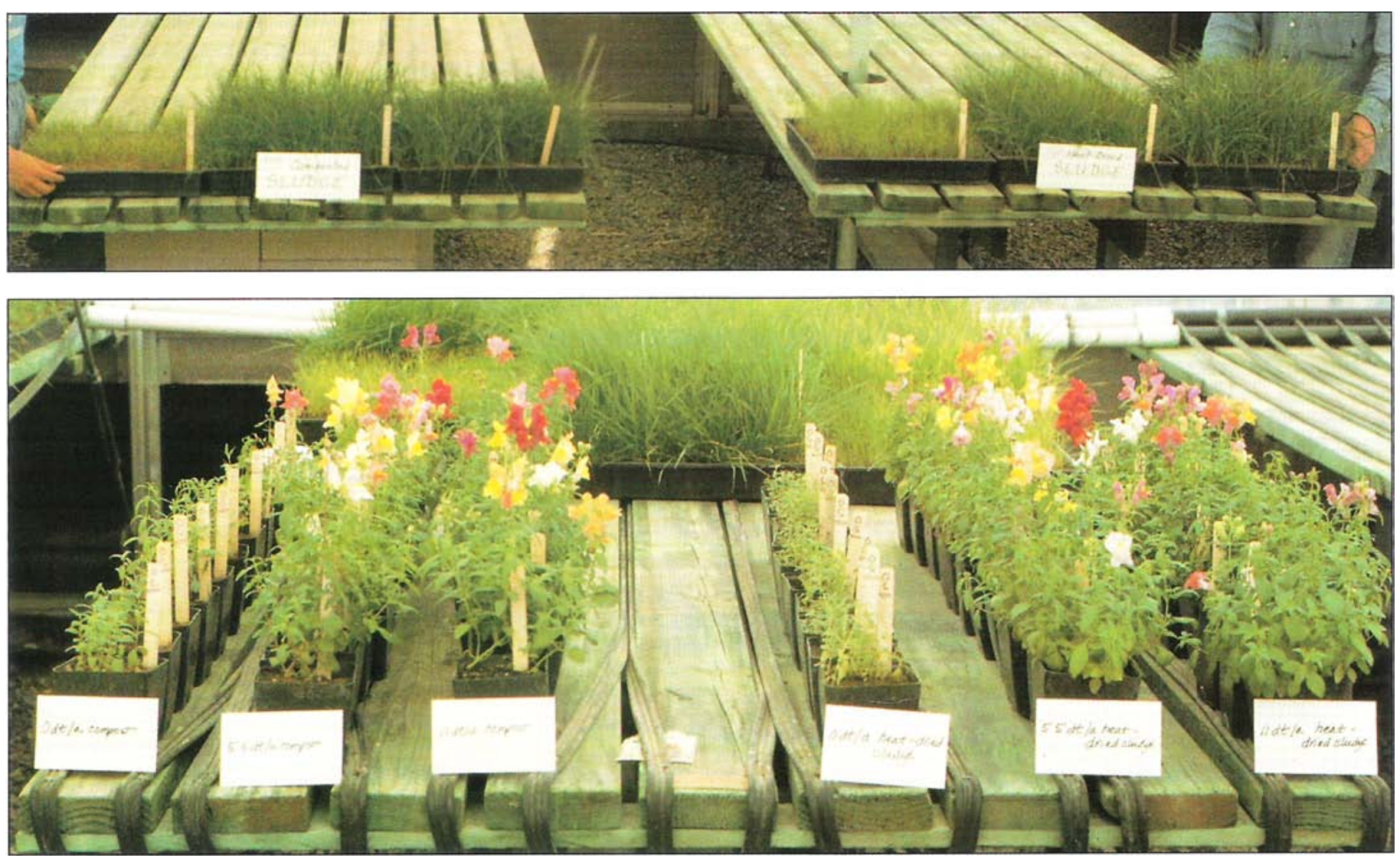

Top: Turf responds dramatically to sludge amendments as demonstrated in the greenhouse experiment. Sludge products may receive expanded use in large-scale turf plantings.

Below: Concurrent greenhouse trials in pots, like the field studies, document the positive response of test crops to sludge products.

\title{
Crop response to sewage sludge compost: a preliminary report
}

\author{
Robert F. Bevacqua $\square \quad$ Valerie J. Mellano
}

\author{
Municipal sewage sludge, \\ amended with Eucalyptus tree trim- \\ mings and composted, is being \\ evaluated in San Diego as a soil \\ amendment for field and green- \\ house plantings of onion, snap- \\ dragon, turf and spinach. So far, in- \\ creases in yields have been \\ significant. In greenhouse studies \\ comparing compost containing Eu- \\ calyptus trimmings with heat-dried \\ sludge, results show both materi- \\ als equally beneficial to crop \\ growth. The presence of Eucalyp- \\ tus did not decrease yields.
}

The city of San Diego has embarked on a pilot project to explore composting versus heat-drying in recycling sewage sludge produced at Point Loma Waste Water Treatment Plant in Mission Bay. An important aspect of this pilot project is to assess the value of sewage sludge as a soil amendment or soil conditioner for horticultural crops. The authors are presently engaged in this assessment.

During composting, the sludge is mixed with Eucalyptus tree trimmings. The heat generated during composting kills human pathogens and weed seeds, degrades some organic chemicals, and renders the product odorless. The composting is done according to Environmental Protection Act (EPA) regulations.
This on-going study addresses the following questions:

1. How do horticultural crops, such as vegetables, ornamentals and turf, respond when sewage sludge products are used as soil amendments?

2. How do two products, sludge compost and heat-dried sludge, compare in their effect on crop growth?

3. What is the effect on crop growth of high levels (approximately $60 \%$ by volume) of Eucalyptus tree trimmings in sludge compost?

4. What are the long-term effects on crop yields and soil properties when sludge compost is repeatedly applied?

5. Does heavy metal uptake pose a problem when sludge is used with edible crops? 

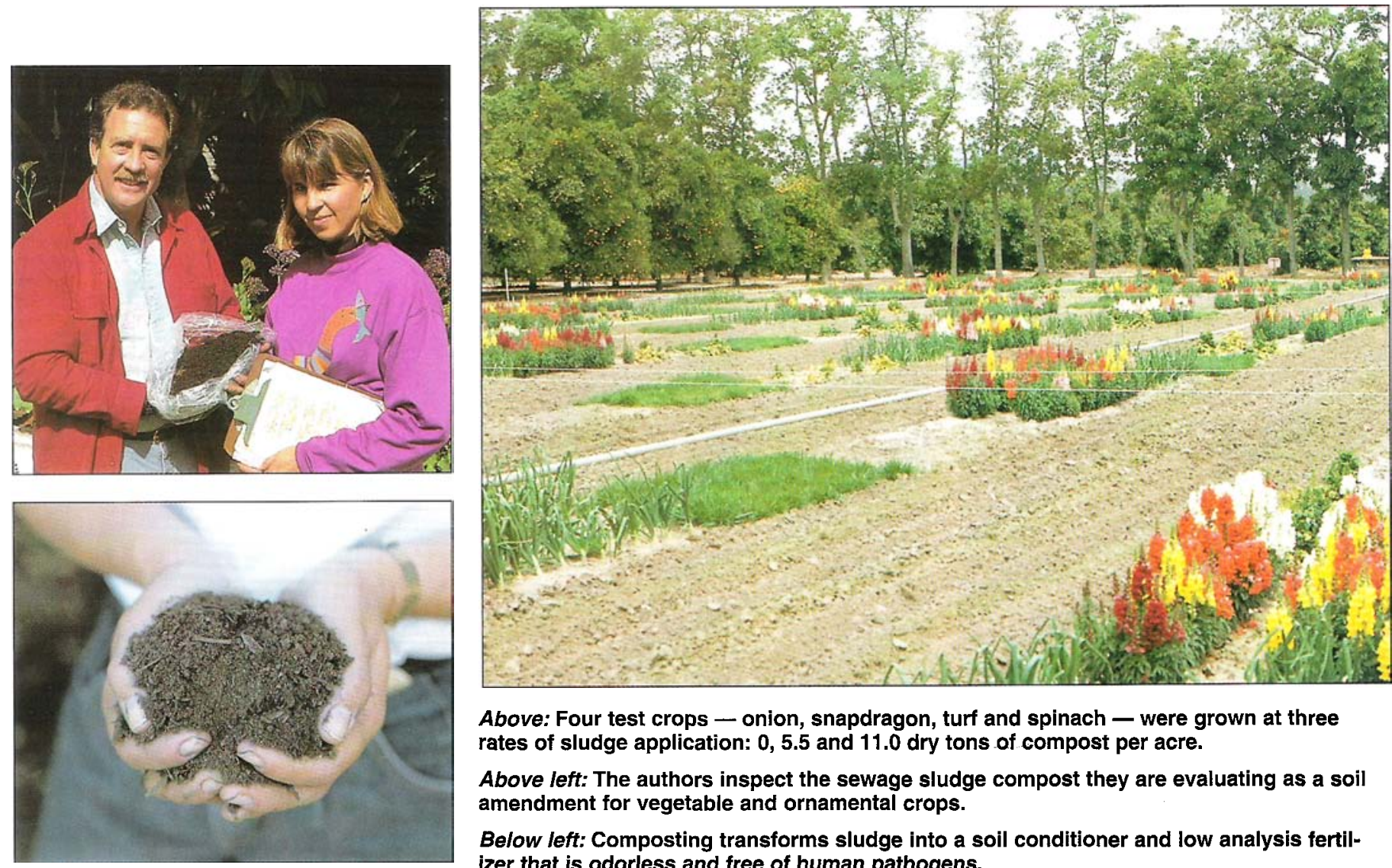

Above: Four test crops - onion, snapdragon, turf and spinach - were grown at three rates of sludge application: $\mathbf{0 , 5 . 5}$ and $\mathbf{1 1 . 0}$ dry tons of compost per acre.

Above left: The authors inspect the sewage sludge compost they are evaluating as a soil amendment for vegetable and ornamental crops.

Below left: Composting transforms sludge into a soil conditioner and low analysis fertilizer that is odorless and free of human pathogens.

The authors wish to emphasize the preliminary nature of this research and the limited applicability of the findings.

\section{Background}

Initiated in 1990 at South Coast Research and Extension Center in Irvine, this consists of a series of field and greenhouse experiments. This report presents the results of one field experiment and one greenhouse experiment.

The soil series is a San Emigdio sandy loam with $\mathrm{pH}$ values that range from neutral to alkaline, organic matter levels less than $1 \%$, slope less than $2 \%$, and a texture that consists of $19 \%$ clay, $28 \%$ silt and $53 \%$ sand. The soil order is entisol; the subgroup is Typic Xerorthents; and the family is coarse-loamy, mixed, calcareous and thermic.

The test crops used in this study are onion, snapdragon, turf and spinach. These crops were chosen as representative of horticultural crops grown in Southern California.

The sludge compost was produced from dewatered sludge composted with tree trimmings and screened. The heatdried sludge was a pelletized product that contained no green waste. Table 1 contains the chemical characteristics of the sludge compost.

\section{Field experiment}

The field experiment's objective was to measure crop response to compost applications. A completely randomized design with replications within treatments was employed. The treatments were 0,5.5 and 11.0 dry tons per acre of composted sewage sludge. Test crops were onion, snapdragon, turf and spinach. Compost was applied with a VICON spreader and rotovated into the top 4 inches of soil. The test crops were field-planted March 13, 1991. Weed control was maintained by Dactal $W-75$ at 8 pounds per acre and by hand. The 0.5 -acre experiment was irrigated once a week with overhead sprinklers at a rate of 13,635 gallons per acre. Visual ratings were made periodically for stand, color and flowering.

\section{Greenhouse experiment}

The greenhouse study's objective was to compare the effect on crop yield of sludge compost with that of heat-dried sludge when each is used as an amendment in a potting mix. The adding of tree trimmings is a point of concern in the composting process. Some authors report Eucalyptus contains allelopathic substances that inhibit growth of other plants. This study assesses the effect on plant growth of Eucalyptus trimmings in compost with a pure sludge product containing no Eucalyptus.

Because of the small amount of heatdried sludge available, a field experiment was not possible. The same four test crops used in the field trials were used in the

TABLE 1. Chemical characteristics of two sludge products: sewage sludge compost and heat-dried sludge

\begin{tabular}{lcc}
\hline \hline Analysis & $\begin{array}{c}\text { Sewage sludge } \\
\text { compost }^{*}\end{array}$ & $\begin{array}{c}\text { Heat-dried } \\
\text { sludge† }\end{array}$ \\
\hline Total nitrogen- $\mathrm{N}(\%)$ & 1.9 & 3.17 \\
Phosphate- $\mathrm{P}_{2} \mathrm{O}_{5}(\%)$ & 0.1 & 0.01 \\
Potash- $\mathrm{K}_{2} \mathrm{O}(\%)$ & 0.6 & 0.06 \\
$\mathrm{pH}$ & 6.4 & 7.1 \\
$\mathrm{EC}(d S / m) \ddagger$ & 17.8 & 11.0 \\
$\mathrm{Ca}(\mathrm{me} / \mathrm{l}) \S$ & 40.0 & 33.0 \\
$\mathrm{Mg}(\mathrm{me} / \mathrm{l})$ & 34.0 & 35.0 \\
$\mathrm{Na}(m e / l)$ & 37.8 & 70.0 \\
$\mathrm{Cl}(\mathrm{me} / \mathrm{l})$ & 59.0 & 51.2 \\
$\mathrm{Cd}(\mathrm{ppm})$ & 5.5 & 3.1 \\
$\mathrm{Ni}(p p m)$ & 30.7 & 10.3 \\
$\mathrm{Zn}(p p m)$ & 125.0 & 275.0 \\
Organic matter $(\%)$ & 41.8 & 49.2 \\
\hline
\end{tabular}

*Data from University of California Division of Agriculture and Natural Resources Analytical Laboratory R-90-S-181.

†Data from University of California Division of Agriculture and Natural Resources Analytical Laboratory D-92-S-92.

†Decisiemens per meter, a measure of soil electrical conductivity which reflects soil salinity.

$\S$ Milliequivalents per liter, a measure of concentration. 
greenhouse study: onion, snapdragon, turf, and spinach. Sludge compost and soil mix and heat-dried sludge and soil mix were combined in appropriate ratios so as to be equivalent to the sludge compost rates used in the field experiments: $0,5.5$ and 11.0 dry tons per acre.

Every cubic foot of soil mix used in the greenhouse consisted of one-third peat moss, one-third sand, one-third top soil (sterilized San Emigdio sandy loam), 1.33 ounces dolomite lime and 0.68 ounce single superphosphate.

The experiment was planted on March 27,1991 . The onion, snapdragon and spinach were seeded directly into 4-inch pots, four seeds per pot. Ten replications were conducted. The turf was seeded to 16inch-square flats.

Plants were visually assessed periodically for stand and color. Plant height was also recorded. At termination, the fresh weight yield of each plant's harvestable parts was determined.

\section{Results}

All test crops in the field experiment benefited from compost applications (table 2). Yields for onion, turf and spinach were significantly increased (5\% level) by adding 5.5 or 11 dry tons of compost per acre; snapdragon yields were significantly increased with the adding of 11 tons of compost per acre. Also, compost applications favored early stand development. Stands

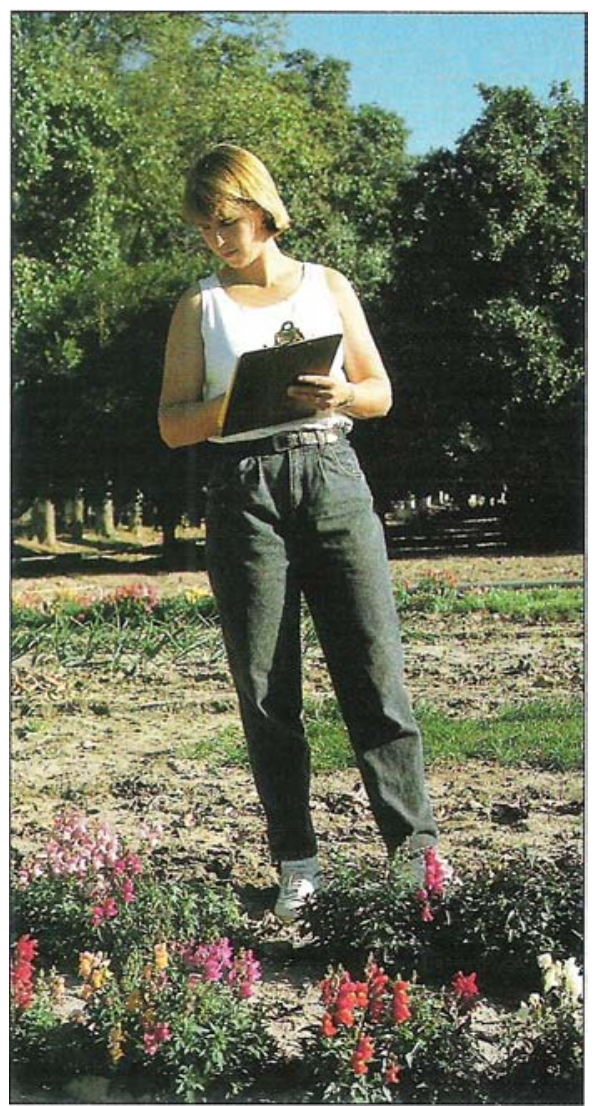

Author Mellano periodically assesses test crops for stand or vigor and color of leaves. Compost encourages early establishment of crops.

TABLE 2. Yield of test crops in the field experiment grown at different rates of sewage sludge compost applied as a soil amendment, 1991

\begin{tabular}{|c|c|c|c|c|}
\hline \multirow[b]{2}{*}{ Compost treatment } & \multicolumn{4}{|c|}{ Fresh wt * } \\
\hline & Onion & Snapdragon & Turft & Spinach \\
\hline dry ton/ac & \multicolumn{4}{|c|}{ 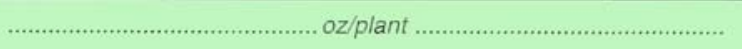 } \\
\hline 0 & $8.5 b$ & $21.7 b$ & $0.5 \mathrm{c}$ & $3.6 \mathrm{c}$ \\
\hline 5.5 & $12.9 \mathrm{a}$ & $25.9 a b$ & $10.1 \mathrm{~b}$ & $7.4 \mathrm{~b}$ \\
\hline 11.0 & $12.4 \mathrm{a}$ & 26.6 a & $20.1 \mathrm{a}$ & $8.9 \mathrm{a}$ \\
\hline
\end{tabular}

"Mean separation within columns by Duncan's multiple range test, $5 \%$ level.

†For turf, fresh weight measures the cuttings from 1 square yard cut at a mower height of 1.5 inches.

TABLE 3. Yield of test crops in the greenhouse experiment grown with two sewage sludge products, compost or heat-dried sludge, at different rates as a soil amendment, 1991

\begin{tabular}{|c|c|c|c|c|c|}
\hline \multirow{2}{*}{$\begin{array}{l}\text { Sludge } \\
\text { product }\end{array}$} & \multirow[b]{2}{*}{ Treatment } & \multicolumn{4}{|c|}{ Fresh wt * } \\
\hline & & Onion & Snapdragon & Turft & Spinach \\
\hline & dry ton/ac & ............ & . & . & ................. \\
\hline Compost & $\begin{array}{c}0 \\
5.5 \\
11.0\end{array}$ & $\begin{array}{l}0.06 \mathrm{c} \\
0.53 \mathrm{a} \\
0.47 \mathrm{a}\end{array}$ & $\begin{array}{l}0.10 c \\
0.64 b \\
0.68 b\end{array}$ & $\begin{array}{l}1.39 \mathrm{~d} \\
5.82 \mathrm{c} \\
8.25 \mathrm{a}\end{array}$ & $\begin{array}{l}0.03 \mathrm{~d} \\
0.25 \mathrm{bc} \\
0.32 \mathrm{a}\end{array}$ \\
\hline Heat-dried & $\begin{array}{c}0 \\
5.5 \\
11.0\end{array}$ & $\begin{array}{l}0.02 c \\
0.26 b \\
0.27 b\end{array}$ & $\begin{array}{l}0.07 \mathrm{c} \\
0.75 \mathrm{~b} \\
0.92 \mathrm{a}\end{array}$ & $\begin{array}{l}1.17 \mathrm{~d} \\
5.29 \mathrm{c} \\
7.04 \mathrm{~b}\end{array}$ & $\begin{array}{l}0.03 \mathrm{~d} \\
0.21 \mathrm{c} \\
0.28 \mathrm{ab}\end{array}$ \\
\hline
\end{tabular}

Mean separation within columns by Duncan's multiple range test, $5 \%$ level.

†For turf, fresh weight measures the cuttings from 0.2 square yard cut at a mower height of 1.5 inches.

rated visually 5 weeks after planting (data not shown) revealed compost applications benefited stand establishment for all test crops.

The greenhouse experiment compared two sludge products, compost and heatdried sludge, as amendments to potting soil. All four test crops responded positively to the two sludge products (table 3 ). Compost treatments produced higher yields in onion and turf; heat-dried sludge produced higher yields in snapdragon. Spinach responded similarly to both products. A repetition of this experiment reinforced the finding that all test crops responded positively to the two sludge products.

The finding that both sludge products similarly affect crop growth indicates $E u$ calyptus trimmings (present in the compost, but not in the heat-dried sludge) do not suppress crop growth at the rates being evaluated in this study. This is an important point because it was initially feared that allelopathic compounds in the Eucalyptus would inhibit crop growth. The authors hypothesize that the composting process degrades the allelopathic compounds into harmless products.

In summary, the field experiment showed that incorporating sewage sludge compost 4 inches deep as a soil amendment in spring plantings significantly increased yields of onion, snapdragon, turf and spinach. Greenhouse experiments produced similar results and demonstrated that the presence of Eucalyptus trimmings in compost does not depress yields.

\section{The future}

There is concern that using sludge compost can lead to the buildup in soil and crop tissues of heavy metals, such as cadmium, nickel and zinc. There is also concern that the buildup of soluble salts or changes in soil $\mathrm{pH}$ can lead to depressed crop growth. The authors are addressing these concerns by amending soil with sludge compost each fall and spring in continuing field experiments. Future work will also compare the effects of applying sludge compost with applying commercial nitrogen fertilizer.

\section{R. F. Bevacqua is Superintendent of South} Coast Research and Extension Center, Irvine, and V.J. Mellano is Farm Advisor for Environmental Issues, San Diego County.

The authors gratefully acknowledge the technical support of the staff at South Coast Research and Extension Center. Thanks go to John Beyl, Dave Lillard, John Peterson, Herman Redd, Tim Melby, George Nieblas, Dennis Walker, Sunny Burns and Trish Harrison. 